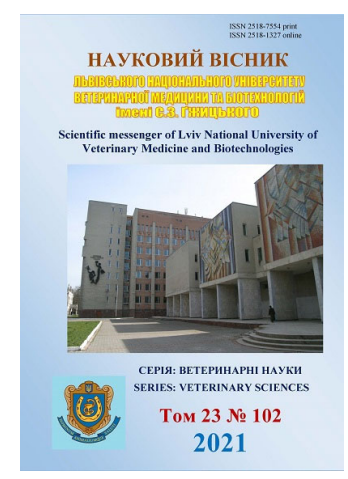

Науковий вісник Яьвівського національного університету ветеринарної медицини та біотехнологій імені С.3. Гжицького. Серія: Ветеринарні науки

\author{
Scientific Messenger of Lviv National University \\ of Veterinary Medicine and Biotechnologies. \\ Series: Veterinary sciences
}

UDC 616.995.1:636.5(477.53)

\title{
Distribution of nematodoses of poultry in farms of Poltava region
}

\author{
L. Korchan, A. Zamaziy \\ Poltava State Agrarian Academy, Poltava, Ukraine
}

Article info

Received 22.02.2021

Received in revised form 29.03.2021

Accepted 30.03.2021

Poltava State Agrarian Academy, Skovorody Str., 1/3,

Poltava, 36003, Ukraine. Tel.: +38-095-158-85-78

E-mail: korchanl98@gmail.com
Korchan, L., \& Zamaziy, A. (2021). Distribution of nematodoses of poultry in farms of Poltava region. Scientific Messenger of Lviv National University of Veterinary Medicine and Biotechnologies. Series: Veterinary sciences, 23(102), 3-7. doi: 10.32718/nvlvet10201

The task of meeting the needs of the population with high-quality poultry products is to create a stable veterinary welfare in farms of various forms of ownership by in-depth study of the epizootic situation of nematodoses, which are registered in poultry. This will effectively develop and implement a system of treatment and prevention measures and reduce the incidence and death of poultry, especially from mixed helminthiasis. The aim of the work was to study the species composition, distribution and features of the course of nematodoses of the digestive tract in poultry in the farms of Poltava region. A total of 241 coprooscopic studies of chickens and 186 - geese were performed. Parasitological studies have shown that nematodoses of the digestive tract among domestic geese and chickens in farms of Poltava region are very common invasive diseases, where the extensiveness of invasion ranges from 16.59 to $74.69 \%$. In the studied chickens, pathogens of heterakosis (EI-74.69\%), ascaridiosis (41.49\%), capillariosis (31.54\%), trihostrongilosis $(16.59 \%)$ were detected. Among the studied geese, pathogens of heterakosis (41.94\%), amidostomosis $(27.42 \%)$, capillariosis $(25.81 \%)$ and trihostrongilosis $(16.67 \%)$ were found. It is proved that nematodoses of the digestive tract mainly occur in the form of polyinvasions. In $67.22 \%$ of patients with nematodoses of chickens, the simultaneous course of several parasitic pathogens was established, in geese this figure was $57.69 \%$. Monoinvasions were detected in 32.78 and $42.31 \%$ of patients with nematodoses of chickens and geese, respectively. Out of the polyinvasions of chickens, two-component ones predominated, where heterakosis-capillariosic and ascaridiosis-heterakosic were most often diagnosed (51.24 and 33.06\% of patients with polyinvasions). Ascaridiosis-trihostrongilosis-capillariosic (9.92\%) and heterakosistrihostrongilosis-capillariosic $(5.78 \%)$ invasions were less frequent. Among geese, heterakosiscapillariosic (40\% of patients with polyinvasions) and amidostomosis-capillariosic (28.89\%) invasions dominated among polyinvasions. A smaller percentage were heterakosis-amidostomosis-capillariosic (20\%) and amidostomosis-trihostrongilosis (11.11\%) invasions. Prospects for further research are to establish the effectiveness of modern anthelmintics in polyinvasions of geese and chickens.

Key words: nematodoses, chickens, geese, distribution, extensiveness of invasion, polyinvasions.

\section{Поширення нематодозів домашньої птиці у господарствах Полтавської області}

\author{
Л. М. Корчан, А. А. Замазій
}

Полтавська державна аграрна академія, м. Полтава, Украӥна

\footnotetext{
Завданням забезпечення потреб населення високоякісною продукиією птахівництва є створення стабільного ветеринарного благополуччя у господарствах різної форми власності шляхом поглибленого вивчення епізоотичної ситуації нематодозів, які реєструються у домашньої птиці. Це дозволить ефективно розробляти та впроваджувати систему лікувально-профілактичних заходів та знизити захворюваність і падіж птахів, особливо від зміманих гельмінтозів. Метою роботи було вивчити видовий склад, поширення та особливості перебігу нематодозів травного тракту у домашньої птиці в умовах господарств Полтавської області. Всього проведено 241 копроовоскопічне дослідження курей та 186 - гусей. Проведеними паразитологічними дослідженнями встановлено, що нематодози травного тракту серед домашніх гусей та курей у господарствах Полтавської області є знач-
} 
но поширеними інвазійними захворюваннями, де екстенсивність інвазї коливається від 16,59 до 74,69\%. У досліджених курей виявляли збудників гетеракозу (EI - 74,69\%), аскаридіозу (41,49\%), капіляріозу (31,54\%), трихостронгільозу (16,59\%). Серед досліджених гусей виявлено збудників гетеракозу (41,94\%), амідостомозу (27,42\%), капіляріозу (25,81 \%) та трихостронгільозу (16,67\%). Доведено, що нематодози травного тракту, переважно, перебігають у вигляді полінвазій. У 67,22 \% хворих на нематодози курей встановлено одночасний перебіг декількох збудників паразитозів, у гусей ией показник становив 57,69 \%. Моноінвазіі виявлено у 32,78 та 42,31 \% хворих на нематодози курей та гусей відповідно. 3 поліінвазій курей переважали двокомпонентні, де найчастіше діагностували гетеракозно-капіляріозну та аскаридіозно-гетеракозну (51,24 та 33,06\% від хворих на поліінвазіі). Рідше виявляли аскаридіозно-трихостронгільозно-капіляріозну (9,92 \%) та гетеракозно-трихостронгільозно-капіляріозну (5,78 \%) інвазії. У гусей серед поліінвазій домінували гетеракозно-капіляріозна (40\% від хворих на поліінвазії) та амідостомознокапіляріозна (28,89\%) інвазіі. Менший відсоток становили гетеракозно-амідостомозно-капіляріозну (20\%) та амідостомознотрихостронгільозну (11,11\%) інвазіі. Перспективами подальших досліджень є встановлення ефективності сучасних антигельмінтиків за полінввазій гусей та курей.

Ключові слова: нематодози, кури, гуси, поширення, екстенсивність інвазії, полїнвазії.

\section{Вступ}

Птахівництво є однією з важливих галузей тваринництва в усьому світі, яка за останні роки набула значного розвитку, особливо промислове птахівництво, з використанням сучасної технології виробництва яєць і м'яса птиці різних видів. В особистих селянських та фермерських господарствах птахівництво також має тенденцію розвитку. Стримуючим фактором у розвитку птахівництва $\epsilon$ інфекційні та інвазійні хвороби, особливо гельмінтози (Shi et al., 2008; Islam et al., 2016; Elmberg et al., 2017).

Останнім часом однією з актуальних проблем птахівництва, особливо в умовах приватних невеликих господарств, є нематодози, які завдають галузі значні економічні збитки. Останні зумовлені зростанням витрат кормів на одиницю продукції, відставанням у рості і розвитку птиці, особливо молодняку, нерідко відбувається його загибель. Гельмінти сприяють виникненню гіповітамінозів, ослаблюють загальну резистентність організму, сприяють проникненню в органи i тканини збудників інфекційних захворювань (Magwisha et al., 2002; Hassouni \& Belghyti, 2006; Kornaś et al., 2015; Afolabi et al., 2016; Hamadani et al., 2017).

Зокрема, на території Нігерії показники інвазованості домашньої птиці нематодоми травного каналу коливалися від 42,5 до 100,0 \% (Uhuo et al., 2013; Adang et al., 2014; Jegede et al., 2015). У господарствах Бангладешу та Ірану науковці встановили, що екстенсивність інвазії збудниками шлунково-кишкових гельмінтозів у дослідженої птиці становила відповідно 84,6 та 91,9 \% (Alam et al., 2014; Ferdushy et al., 2016).

Більшість науковців зазначають, що найбільш поширеними нематодозами домашньої птиці є Heterakis gallinarum, Ascaridia galli, Amidostomum anseris та Heterakis dispar, що пов'язане 3 високою стійкістю екзогенних стадій розвитку нематод у зовнішньому середовищі, а також особливістю їх життєвого циклу. Також автори доводять, що гельмінтози у птиці дуже часто перебігають у вигляді поліінвазій, що призводить до ускладнення клінічного перебігу захворювання (Taylor et al., 2007; Nnadi \& George, 2010; Ebrahimi et al., 2014).

У зв'язку з вищенаведеним, метою роботи було вивчити видовий склад, поширення та особливості перебігу нематодозів травного тракту у домашньої птиці в умовах господарств Полтавської області.

\section{Матеріал і методи досліджень}

Роботу виконували упродовж 2020-2021 pp. на базі лабораторії кафедри паразитології та ветеринарносанітарної експертизи Полтавської державної аграрної академії, а також в умовах одноосібних селянських і фермерських птахівничих господарств Полтавської області (Лубенського, Гадяцького, Котелевського, Полтавського районів). Інвазованість домашньої птиці встановлювали за показником екстенсивності інвазiі (EI, \%). Копроовоскопічні дослідження проводили за методом В. Н. Трача (Trach, 1992). Визначення видової належності яєць паразитів проводили за допомогою атласів диференціальної діагностики гельмінтозів (Cherepanov et al., 1999). Всього проведено 241 копроовоскопічне дослідження курей та 186 - гусей.

\section{Результати та їх обговорення}

Результатами проведених досліджень встановлено, що нематодози травного тракту серед домашніх гусей та курей у господарствах Полтавської області є значно поширеними інвазійними захворюваннями де екстенсивність інвазії коливається від 16,59 до 74,69 \%. Зокрема, у курей виявлено збудників гетеракозу (ЕI $74,69 \%$ ), аскаридіозу $(41,49 \%)$, капіляріозу $(31,54 \%)$ та трихостронгільозу (16,59\%). Серед досліджених гусей виявлено збудників гетеракозу (ЕI - 41,94 \%), амідостомозу $(27,42 \%)$, капіляріозу $(25,81 \%)$ та трихостронгільозу $(16,67 \%)$ (табл. 1).

\section{Таблиця 1}

Поширення нематодозів травного тракту домашньої птиці на території Полтавської області

\begin{tabular}{lcc}
\hline \multirow{2}{*}{ Інвазія } & \multicolumn{2}{c}{ ЕІ, \% } \\
\cline { 2 - 3 } & Кури $(\mathrm{n}=241)$ & Гуси $(\mathrm{n}=186)$ \\
\hline Гетеракоз & 74,69 & 41,94 \\
Аскаридіоз & 41,49 & - \\
Амідостомо3 & - & 27,42 \\
Капіляріо3 & 31,54 & 25,81 \\
Трихостронгільо3 & 16,59 & 16,67 \\
\hline
\end{tabular}

Водночас, виявлені інвазії перебігали здебільшого, у вигляді поліінвазій. У курей одночасний перебіг декількох збудників нематодозів встановлено у $67,22 \%$ хворої на гельмінтози птиці, у гусей $57,69 \%$. Водночас моноінвазії виявлено у 32,78 та 
42,31 \% хворих на нематодози курей та гусей відповідно (рис. 1).

У досліджених курей мікстінвазії були представлені дво - та трикомпонентними асоціаціями нематод: гетеракозно-капіляріозну $(51,24$ \% від хворих на поліінвазіі), аскаридіозно-гетеракозну (33,06 \%), аскаридіозно-трихостронгільозно-капіляріозну $\quad(9,92 \%)$, гетеракозно-трихостронгільозно-капіляріозну $(5,78$ \%) (рис. 2).
У досліджених гусей, також виявляли дво - та трикомпонентні мікстінвазіі. Домінували гетеракознокапіляріозна (40 \% від хворих на поліінвазії) та амідостомозно-капіляріозна $(28,89 \%)$ інвазії. Рідше виявляли гетеракозно-амідостомозно-капіляріозну (20\%) та амідостомозно-трихостронгільозну $(11,11 \%)$ інвазії (рис. 3).
Моноінвазії $\square$ Поліінвазії

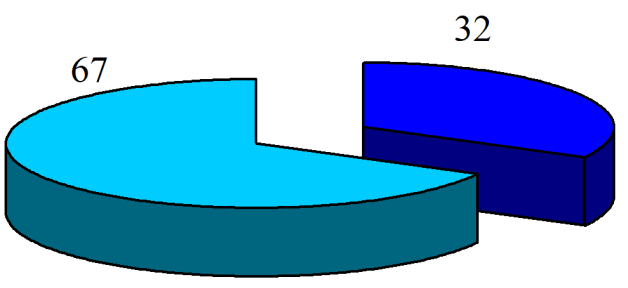

a $\square$ Моноінвазії $\square$ Поліїввазії

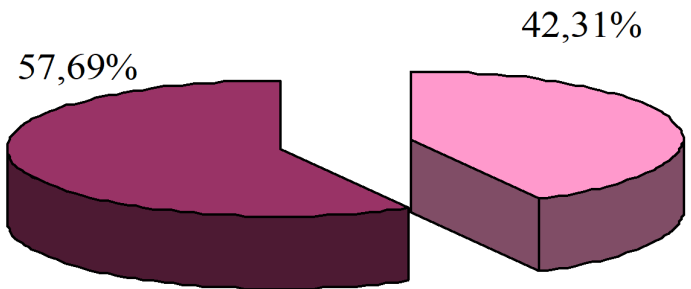

б

Рис 1. Особливості перебігу нематодозів травного тракту в домашньої птиці: а - кури, б - гуси
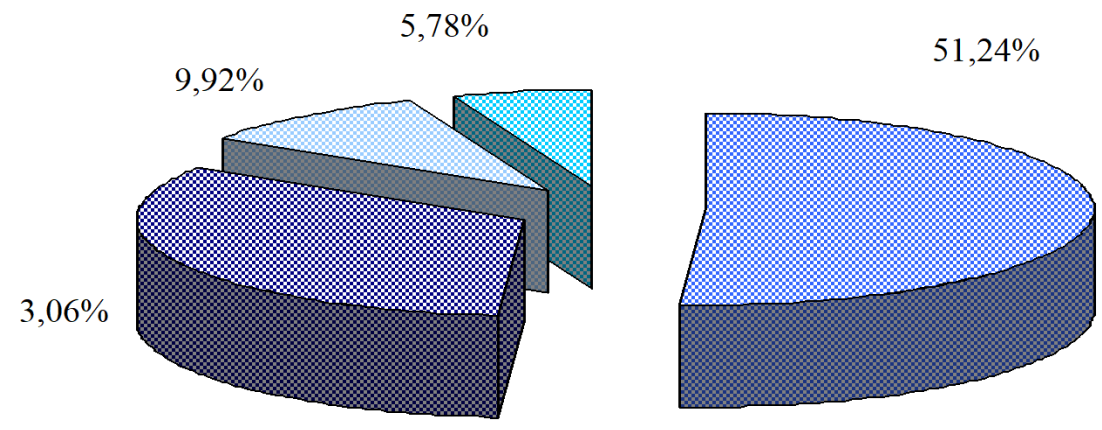

图 $\Gamma+\mathrm{K} \quad \mathrm{A}+\Gamma \quad$ 吕 $\mathrm{A}+\mathrm{T}+\mathrm{K} \quad$ 圆 $\Gamma+\mathrm{T}+\mathrm{K}$

Рис 2. Склад збудників поліінвазій, виділених від курей: А - аскаридіоз, Г - гетеракоз, К - капіляріоз, Т - трихостронгільоз

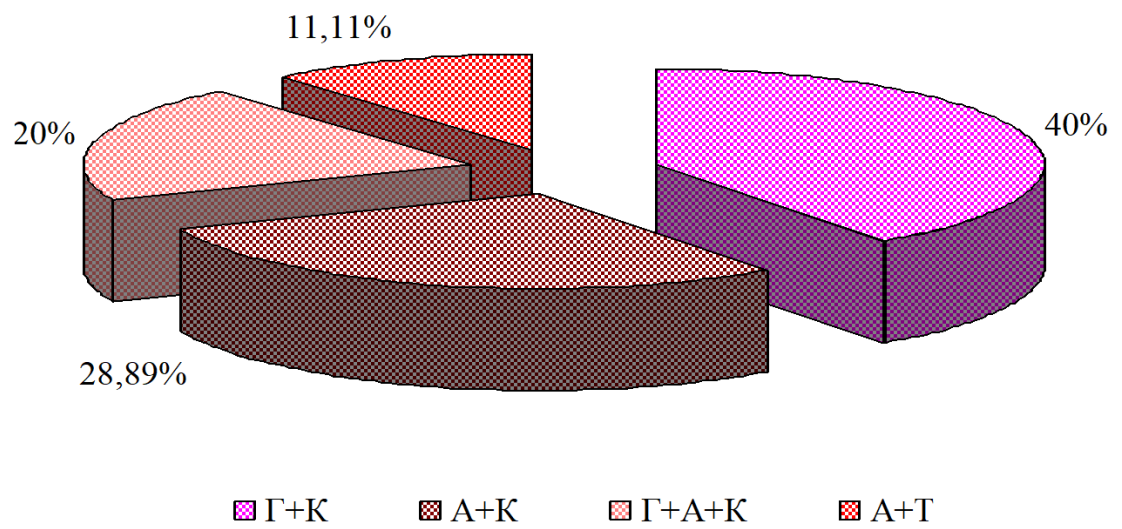

Рис 3. Склад збудників поліінвазій, виділених від гусей:

Г - гетеракоз, К - капіляріо3, А - амідостомоз, Т - трихостронгільоз

Отримані нами дані вказують на значне поширення нематодозів травного тракту серед домашньої птиці у господарствах Полтавської області. У курей діагностовано гетеракоз, аскаридіоз, капіляріоз та трихостронгільоз, у гусей - гетеракоз, амідостомоз, капіля- ріоз та трихостронгільоз. Про значне розповсюдження цих збудників на території господарств різної форми власності Полтавської області свідчать результати наукових досліджень авторів (Yevstafieva et al., 2018; Yevstafieva et al., 2019). Так, у птахогосподарствах із 
підлоговою системою утримання курей середня екстенсивність капіляріозної інвазії становила 30,78 \% за інтенсивності інвазії - 23,57 $\pm 0,42$ яєць у 1 г посліду (Yevstafieva \& Natjaglaja, 2016). Водночас, у домашніх гусей (Anser anser dom.) виділено два види збудників капіляріозу: Baruscapillaria anseris (EI $46,76 \%)$ та Baruscapillaria obsignata (EI - 23,98\%). 3а копроовоскопічними дослідженнями птиці середня екстенсивність капіляріозної інвазії становить $28,72 \%$, за результатами гельмінтологічного розтину $-57,79 \%$ (Yevstafieva et al., 2018).

Також, більшість вчених вказують на те, що гельмінтози у птиці найчастіше перебігають у вигляді поліінвазій (Nnadi \& George, 2010; Ebrahimi et al., 2014). Наші дані, також, вказують на домінування поліінвазій у домашньої птиці, де захворювання супроводжується одночасним паразитуванням від двох до трьох нематод.

\section{Висновки}

Нематодози травного каналу є поширеними інвазіями домашньої птиці у господарствах Полтавської області (ЕІ коливається від 16,59 до 74,69\%). Кури інвазовані гетеракісами (ЕI - 74,69\%), аскаридіями (41,49\%), капіляріями $(31,54 \%)$, трихостронгілюсами, гуси - гетеракісами $(41,94 \%)$, амідостомами (27,42\%), капіляріями (25,81\%), трихостронгілюсами $(16,67 \%)$. Доведено, що у 51,69-67,22 \% хворої на нематодози птиці захворювання перебігали у вигляді поліінвазій.

Відомості про конфлікт інтересів. Автори стверджують про відсутність конфлікту інтересів щодо їх вкладу та результатів досліджень.

\section{References}

Adang, K. L., Asher, R., \& Abba, R. (2014). Gastrointestinal helminths of domestic chickens Gallus gallus domestica and ducks Anas platyrhynchos slaughtered at Gombe main market, Gombe state, Nigeria. Asian Journal of Poultry Science, 8(2), 32-40. doi: 10.3923/ajpsaj.2014.32.40.

Afolabi, O. J., Simon-Oke, I. A., \& Olasunkanmi, A. O. (2016). Intestinal parasites of domestic chicken (Gallus gallus domesticus) in Akure, Nigeria. Journal of Biomedicine, 1(4), 1-4.

Alam, M. N., Mostofa, M., Khan, M. A. H., Alim, M. A., Rahman, A. K. M., \& Trisha, A. A. (2014). Prevalence of gastrointestinal helminth infections in indigenous chickens of selected areas of Barisal district, Bangladesh. Bangladesh Journal of Veterinary Medicine, 12(2), 135-139. URL: https://citeseerx.ist.psu.edu/viewdoc/download?doi=1 0.1.1.959.3489\&rep=rep1\&type=pdf.

Cherepanov, A. A., Moskvin, A. S., Kotel'nikov, G. A., \& Hrenov, V. M. (1999). Differencial'naja diagnostika gel'mintozov po morfologicheskoj strukture jaic i lichinok vozbuditelej. Moskva (in Russian).

Ebrahimi, M., Asadpour, M., Khodaverdi, M., \& Borji, H. (2014). Prevalence and distribution of gastrointestinal helminths in free-range chickens in Mashhad, Northeast of Iran. Systematic Parasitology, 15(1-4), 38-42. URL: https://www.cabdirect.org/cabdirect/abstract/20153182 656.

Elmberg, J., Berg, C., Lerner, H., Waldenström, J., \& Hessel, R. (2017). Potential disease transmission from wild geese and swans to livestock, poultry and humans: a review of the scientific literature from a One Health perspective. Infection Ecology \& Epidemiology, 7(1), 1300450. doi: 10.1080/20008686.2017.1300450.

Ferdushy, T., Hasan, M. T., \& Golam Kadir, A. K. (2016). Cross sectional epidemiological investigation on the prevalence of gastrointestinal helminths in free range chickens in Narsingdi district, Bangladesh. Journal of Parasitic Diseases, 40(3), 818-822. doi: 10.1007/s12639-014-0585-5.

Hamadani, H., Khan, A. A., Wani, Z. A., Jalal, H., Bihaqi, S. J. A., \& Mir, M. S. (2017). Parasitic profile of domestic geese of Kashmir. International Journal of Livestock Research, 7(5), 129-133. doi: 10.5455/ijlr.20170409094535.

Hassouni, T., \& Belghyti, D. (2006). Distribution of gastrointestinal helminths in chicken farms in the Gharb region-Morocco. Parasitology Research, 99(2), 181-183. doi: 10.1007/s00436-006-0145-8.

Islam, M. F., Mia, M. M., Rahman, M. A., \& Bhowmik, N. (2016). Morphometric, productive and reproductive traits of indigenous goose of Bangladesh. Animal Genetic Resources, 59, 37-45. doi: $10.1017 / \mathrm{S} 2078633616000254$.

Jegede, O. C., Asadu, I. A., Opara, M., Obeta, S. S., \& Olayemi, D. O. (2015). Gastrointestinal parasitism in local and exotic breeds of chickens reared in Gwagwalada Guinea Savannah zone of Nigeria. Sokoto Journal of Veterinary Sciences, 13(3), 25-30. doi: 10.4314/sokjvs.v13i3.5.

Kornaś, S., Basiaga, M., Kowal, J., Nosal, P., Wierzbowska, I., \& Kapkowska, E. (2015). Zatorska goose - a subject of parasitological research. Annals of Parasitology, 61(4), 253-256. doi: 10.17420/ap6104.15.

Magwisha, H. B., Kassuku, A. A., Kyvsgaard, N. C., \& Permin, A. (2002). A comparison of the prevalence and burdens of helminth infections in growers and adult freerange chickens. Tropical Animal Health and Production, 34(3), 205-214. doi: 10.1023/a:1015278524559.

Nnadi, P. A., \& George, S. O. (2010). A cross-sectional survey on parasites of chickens in selected villages in the subhumid zones of South-eastern Nigeria. Journal of Parasitology Rresearch, 141824. doi: $10.1155 / 2010 / 141824$.

Shi, Z. D., Tian, Y. B., Wu, W., \& Wang, Z. Y. (2008). Controlling reproductive seasonality in the geese: a review. World's Poultry Science Journal, 64(3), 343355. doi: 10.1017/S0043933908000081.

Taylor, M. A., Coop, R. L., \& Wall, R. L. (2007). Veterinary Parasitology. 3rd ed. Oxford: Blackwell Publishing Ltd. 
Trach, V. N. (1992). Rekomendacii po primeneniju novogo metoda ucheta jaic gelmintov i cist prostejshih $\mathrm{v}$ fekalijah zhivotnyh. Kiev (in Russian).

Uhuo, A. C., Okafor, F. C., Odikamnoro, O. O., Onwe, C. S., Abarike, M. C., \& Elom, J. N. (2013). Common gastrointestinal parasites of local chicken (Gallus domesticus) slaughtered in some selected eatery centers in Abakaliki, Ebonyi state: Implication for meat quality. International Journal of Development and Sustainability, 2(2), 1416-1422.

Yevstafieva, V.A., Stybel, V. V., Melnychuk, V. V., Prijma, O. B., Yatsenko, I. V., Antipov, A. A., Bakhur, T. I., Goncharenko, V. P., Pidborska, R. V., Shahanenko, V. S., \& Dzhmil, V. I. (2019). Morphological and Biological Characteristics of Amidostomum anseris (Nematoda, Amidostomatidae) from Anser anser domesticus. Vestnik Zoologii, 53(1), 65-74. doi: 10.2478/vzoo-2019-0007.

Yevstafieva, V. A., Yeresko, V. I., Pishchalenko, M. A., \& Nagorna, L. V. (2018). Differential species characters of Baruscapillaria anseris and B. obsignata nematodes obtained from the domestic goose. Regulatory Mechanisms in Biosystems, 9(4), 578-583. doi: 10.15421/021886.

Yevstafyeva, V. A., \& Natjaglaja, I. V. (2016). Rasprostranenie kapilljarioza kur na territorii Poltavskoj oblasti. Uchenye zapiski uchrezhdenija obrazovanija "Vitebskaja ordena "Znak pocheta" gosudarstvennaja akademija veterinarnoj mediciny", 52(3), 39-42 (in Russian).

Yevstafyeva, V.A., Melnychuk, V. V., Nikiforova, O. V., Suprunenko, K. V., Korchan, L. N., LokesKrupka, T. P., Nehrebetskyi, I. S., \& Korchan, N. I. (2018). Comparative morphology and biology of nematodes of genus Heterakis (Nematoda, Heterakidae), parasites of the domestic goose (Anser anser) in Ukraine. Regulatory Mechanisms in Biosystems, 9(2), 229-236. doi: 10.15421/021834. 